\title{
RISKS ANALISYS AND MANAGEMENT OF WATER ECOSYSTEMS
}

\section{A. Dychko}

National Technical University of Ukraine "Igor Sikorsky Kyiv Polytechnic Institute"

vul. Borschagivska, 115, Kyiv, 03056, Ukraine. E-mail: aodi@ukr.net

\section{Yeremeev}

Taurida National V. I. Vernadsky University

vul. Ivana Kudri, 33, Kyiv, 04000, Ukraine.

Purpose. The functioning of the water ecosystem management system is characterized by the lack of a systematic approach to the analysis of the state of natural reservoirs, as well as the accurate and operative measurement of the qualitative and quantitative indicators of environmental safety of the hydrosphere. Management of water ecosystems under conditions of fuzzy and incomplete information or decision-making is characterized by the presence of risks that are needed to be taken into account. The aim of the research is insuring the reliability of ecosystem assessment data in the functioning of the water ecosystem management system. Methodology. The methods of system analysis, the theory of fuzzy sets, probability theory, and decision making theory are used in the research. Findings. The analysis of the risks existing during the management of water ecosystems under conditions of indistinct and incomplete information is presented. The risks arising while ecological management of water ecosystems and the main components of riskoriented management of ecosystem are identified. Originality. The relations between factors of processes dynamics and the degree of adequacy, reliability and uniqueness of the ecosystem's response to natural and man-made influences factors are established. The linguistic scale of risk assessments is presented. Practical value. The matrix of the probability of events of the stability of water ecosystems and the consequences of their implementation is made. Under conditions of uncertainty, risk assessment should be simplified to the cross of relevant probabilities of events and the consequences of their implementation for the sustainability of water ecosystems. Conclusions. Risk-oriented management of water ecosystems includes stages of identification, reduction of probability and assessment of risk, development of management measures taking into account the dynamics of ecosystem state change. The determination of the relationship between the factors of the dynamics of processes and the degree of adequacy, reliability and uniqueness of the ecosystem's response to natural and man-made influences can be represented as a sequential transition from one single factor and one parameter with one connection to a complex system under the conditions of a number of factors, parameters and connections that can be combined with extrapolation procedures. References 17, figures 4.

Key words: water ecosystem, risks, management, fuzzy sets, decision making.

\section{А. О. Дичко}

Національний технічний університет України «Київський політехнічний інститут ім. Ігоря Сікорського» вул. Борщагівська, 115, Київ, 03056, Україна. E-mail: aodi@ukr.net

\section{I. С. Сремєєв}

Таврійскій національний університет ім. В.І. Вернадського

вул. Івана Кудрі, 33, Київ, 04000, Україна.

Функціонування системи управління водними екосистемами характеризується відсутністю системного підходу до аналізу стану природних водойм, а також точного і оперативного вимірювання якісних і кількісних показників екологічної безпеки гідросфери. Управління водними екосистемами в умовах нечіткої та неповної інформації або прийняття рішень характеризується присутністю ризиків, які необхідно приймати до уваги. Метою дослідження є забезпечення достовірності даних оцінки екосистеми при функціонуванні системи управління водною екосистемою. У дослідженні використані методи системного аналізу, теорії нечітких множин, теорії ймовірності та теорії прийняття рішень. Представлений аналіз ризиків, що існують при управлінні водними екосистемами в умовах нечіткої та неповної інформації. Ідентифіковано ризики, що виникають при екологічному менеджменті водних екосистем, і основні складові ризик-орієнтованого управлінні екосистемою. Встановлено зв'язки між факторами динаміки процесів і ступенем адекватності, надійності та унікальності реакції екосистеми на природні та антропогенні фактори впливу. 3 метою зменшення ймовірності виникнення ризиків необхідне впровадження ідентифікації ключових покахників, що знижують стійкість екосистеми, встановлення керуючих факторів, зменшення ймовірності та ціни ризику, розробки заходів із пом'якшення кожного 3 ключових ризиків, а також розробки плану збереження стійкості екосистеми. Представлена лінгвістична шкала оцінок ризиків. Розроблено матрицю ймовірності подій стійкості водних екосистем і наслідків їх реалізації. В умовах невизначеності оцінка ризиків повинна бути спрощена до схрещення відповідних ймовірностей подій $і$ наслідків їх реалізації для стійкості водних екосистем. Ризик-орієнтований менеджмент водних екосистем включає етапи ідентифікації, зменшення ймовірності та оцінка ризику, розробки управлінських заходів, приймаючи до уваги динаміку зміни стану екосистеми. Визначення зв'язку між факторами динаміки процесів і ступенем адекватності, надійності і унікальності відгуку екосистеми на природні та антропогенні впливи може бути представлено як послідовний перехід від одного окремого фактора та одного параметра з одним зв'язком до складної системи в умовах набору факторів, параметрів та зв'язків, які можуть комбінуватись процедурами екстраполяції.

Ключові слова: водні екосистеми, ризики, менеджмент, нечіткі дані, прийняття рішень. 
PROBLEM STATEMENT. The functioning of the water ecosystem management system is characterized by the lack of a systematic approach to the analysis of the state of natural reservoirs, as well as the accurate and operative measurement of the qualitative and quantitative indicators of environmental safety of the hydrosphere. Ensuring the reliability of ecosystem assessment data is an urgent problem, because on the basis of these data, a decision should be made on forecasting changes in the stability of water hydrobiocenoses and the necessary measures for protection of surface water bodies and the environment as a whole in the presence of the risk of natural or man-made accidents [1-3].

The integrated ecological-geological methodology for assessing environmental pollution in the first stage is implemented through a system of observations. First, aerospace environmental and geophysical studies are carried out and the areas of possible pollution and probable migration routes are determined, then samples at specific points are taken for geochemical analysis. After some time repeated research is carried out. Comparing their results, the extent of the impact of man-made processes on the environment can be determined. However, it is also necessary to have information on the chemical composition of petroleum products, the ratio of the mass of polluting reagents and soil and the volume of pollution. In addition, other factors (in particular, thermal networks) may also affect the temperature regime of surface layers of the soil. Therefore, this technique can be used at previous stages of contaminants detection with further refinement [4].

The large volume of environmental information accumulated in monitoring surveys, even in the relatively small area of the administrative area, requires the creation of geographic information systems for environmental auditing, environmental monitoring, environmental safety and environmental management, taking into account potential risks [5]. The methodology of geoecological monitoring on the basis of practical researches of the reservations does not take into account the features of other regions, in particular with high man-made load [5].

Assessment of the degree of environmental risk in the case of emergencies and identification soil contamination areas in short time are allowed by a complex of methods $[4,6]$. It includes a methodology for calculating the values of local temperature anomalies in nearsurface layers for assessing soil contamination by petroleum products, also pesticides, tarpaulins, household and industrial wastes, and others like that.

According to the results of research [7] an algorithm of geoecological audit as a complex analysis of the current ecological situation of the territory, modelling and forecasting of its development is worked out. Such algorithm is proposed to be carried out by methods of system research, not 3 , but all 9 components of the environment. It is noted that underestimation or insufficient consideration of the ecological state of one or more components of the environment leads to a biased assessment of its condition. Therefore, the final result of eco-auditing can be obtained only after computer processing of environmental information databases using modern GIS technologies and powerful computer tech- nologies [7]. At the same time, it should be emphasized that eco-auditing is a separate stage of environmental monitoring without its systematic application.

The unification of the methods of analytical determinations of chemical components in the laboratories of various state monitoring agencies allows to intensify observation of points, to install more accurate and effective exchange of information at the international level for the purpose of information support and emergency prevention and also for practical problems solution of supporting decisions related to management of environmental safety of surface water and improvement of the existing system of state monitoring [8].

The functional scheme of the regional environmental monitoring system consists of subsystem of environmental information collection and subsystem of information and analytical analysis [9]. This system is proposed to be integrated to united state system of environmental monitoring, which will monitor the air (water, soil, geological changes, waste, development, public health) basin and control the risks of emergencies. The highest level of this system is a territorial information and analytical centre, which must perform the following functions: obtaining information from informationanalytical centres of the middle level and from the part of automated (stationary and mobile) environmental control systems; continuous analysis of environmental information, trends and ecologically hazardous areas and zones; modelling and forecasting the development of emergencies and their consequences; making recommendations for the adoption of operational decisionmaking in emergencies; formation of a bank of statistical data on the ecological status of individual cities and districts and the entire region in whole; simulation and long-term forecasting the environmental state of ecosystems. Moreover, information and analytical centres solve the problems of identifying the risks of emergency environmental situations and forecast their development in a particular area, taking into account the specifics of local industrial and agricultural production, geographical, climatic and meteorological features [9].

The principles and stages of constructing expert systems of environmental monitoring include the stages of conceptualization, concretization, formalization and implementation of tests. As the main criteria for checking the developed expert system, the quality of decisions is selected, which is evaluated by checking the quality and correctness of judgments while solving real problems, establishing the acceptability of the character of dialogue with the user, defining functional technical and software tools, etc. [10].

At the same time, each situation, regardless of whether it relates to the assessment of the degree of pollution of the hydrosphere or management of natural water bodies in a difficult situation in conditions of indistinct and incomplete information or decisionmaking, is characterized by the presence of risks that need to be taken into account [11].

The management of ecosystems, including water ones, takes place under conditions of limited (incomplete) and indistinct information that affects the effectiveness of self-cleaning and self-healing processes of natural landscapes [12-14]. Indicators of environmental 
safety assessment are not determined online, as a rule, and in addition, certain averaged data is used. At the same time, regulatory influences aimed at achieving effective management may become inadequate to the current situation and there is a risk of losing control of ecosystem sustainability processes.

Modelling the processes of pollution spread and identifying the dynamics of ecological state changes can help to find effective measures to prevent negative impact of pollution on the environment by creating artificial barriers to the migration of these contaminants, or organizing active measures to compensate or neutralize them.

The aim of the research is insuring the reliability of ecosystem assessment data in the functioning of the water ecosystem management system.

MATERIALS AND RESULTS. Modelling and forecasting as components of the management of state of natural and engineering water drainage systems in the presence of pollution sources (natural and anthropogenic) have exceptional importance. On the one hand, while designing industrial enterprises, transport highways, storages of toxic waste, landfills, etc. it is necessary to assess the future impact of these objects on the environmental state, using adequate models of distribution, migration and metabolism of pollution in the average conditions of the operation of these objects throughout the term of their work. On the other hand, using appropriate models can help to identify risks in the event of natural or man-made disasters and formulate scenarios for the elimination of the consequences of such accidents [1516]. Finally, the simulation of pollution spreading processes and the interaction of several existing pollution sources can help to determine source contribution to the actual environmental state and propose measures to compensate or minimize this impact. In addition, using distribution models and accumulation of contaminants can determine both the maximum terms of enterprises operation that pollute the environment and the environmental capacity of water ecosystem and ways to increase it.

From all of the above, the tasks for the successful management of water ecosystems to be solved are:

- selection (development) of mathematical models that adequately reproduce processes of distribution of pollution of different types, their possible forms of existence, different conditions and landscapes;

- selection (development) of mathematical models that adequately reproduce processes of pollution metabolism (processes of transition of contamination from one form of existence to another, if the rates of distribution or certain physical and chemical properties change at the same time, the accumulation effect or, conversely, expansion or transformation effect is present);

- selection of coefficients of models taking into account the specific conditions of the environment in which the migration or metabolism of pollution occurs;

- selection (development) of models of natural or artificial barriers that are able to delay, slow down or fix the distribution of pollution;

- development of scenarios for which emergency emissions or discharges can occur and appropriate measures to minimize the consequences of such emissions (discharges);

- development (selection) both on the basis of sce- narios of emergency emissions (discharges) and by carefully sequential causal analysis of real ecological accidents of possible indicators that could signal that so far stable system with its features can go into a metastable state, which under certain conditions has a significant probability of transforming into an accident.

Management of water ecosystems includes the following components:

- taking into account the main and additional (up to several dozen) parameters characterizing the ecosystem stability process;

- determination of the reasons for the stability reduction depending on the state parameters taking into account a number of parameters of the state and the variety of their characteristics: quantitative (concentration of pollutants, intensity of their migration, etc.), qualitative (hydrobiological characteristics), binary (presence of certain (toxic to the microflora) pollutant - present / absent), etc.;

- creating of ecosystem status databases with information on verified reasons for reducing sustainability and a database of characteristics of self-healing processes that can identify the process.

The main stages of implementation of innovative measures for the effective management of water ecosystems are:

1. Determination the purpose of the application of innovation: what are the most important (unique) features will characterize it, how much will it cost to create the system, who will operate it and who will use the results of the system functioning, which value of these results is expected. For implementing these it is necessary to choose a measure of cost estimation (throughput, productivity, specific product characteristics (accuracy, reliability, environmental friendliness, etc.) or the "efficiency / cost" indicator).

2. Detection of the "bottleneck" of the proposed system, since indicators such as performance or throughput is determined by the "bottleneck". Its features can be shown in the following situations:

- maximum load of the link, although it is not always a feature of the "bottleneck", which finds the problem (sometimes systems are optimized by the principle of maximum load of all resources);

- presence of nodes to which information, materials, technical means, etc. flow;

- presence of equipment, subsystems, facilities stoppage in a closed process.

If obvious features of one or several "bottlenecks" are revealed, this suggests that some corrections should be made in the implementation of innovation.

3. Analysis of the "bottleneck": if the effectiveness of the system is determined by the effectiveness of the "bottleneck", it is necessary, above all, to increase it; if it is a question of the stoppage of the "bottleneck" itself, it is necessary to analyze their causes and eliminate or minimize them. It is necessary to do the following:

- eliminate any minor additional work (operations) that can be transferred to other parts of the system;

- eliminate or limit obstacles;

- ensure the work of the "bottleneck" in a stable mode;

- ensure the use of quality means of production and materials; 
- ensure that priority is given to tasks for a "bottleneck", so that it always serves the most priority tasks;

- provide developers with sufficient information on the required system upgrades. And the developer team leader must accept, classify and prioritize queries and messages, and fixing errors, in case of detection of another error, should be activated to ensure a good balance between the activities of developers working on another iteration (improvement of the system based on the comments received earlier), and a sense of the regular system problems.

4. Subordination of each problem to the problem of "bottleneck". All resources that are not defined by the resources of "bottleneck", should be considered as backup, which, if necessary, can be directed to support "bottleneck". Subordination can be made as follows:

- transfer of less significant work from "bottleneck" to other parts of the system;

- all links of the system should work in accordance with the "bottleneck" regime: no faster or slower, in order to avoid overloading "bottleneck" in the future;

- the work buffer at the input of "bottleneck" should always be more or less complete, but not much;

- the output of "bottleneck" should be equipped with a buffer to ensure stable operation of the system in case of variations on the output "bottleneck";

- all links of the system should submit to the "bottleneck" only qualitative (certified) signals, goods, raw materials, etc.;

- a special team of developers should be completely subordinated to the resolution of problems in the "bottleneck" that arise: in case of any questions, requirements, problems related to performance or delays, urgent attention should be focused on solving these issues;

- on-site representatives must periodically participate in testing the system in order to keep the developers informed of their wishes and comments in a timely manner in order to improve the system;

- on-site representatives and the head of a special team of developers should prepare new iterations for the purpose of improvements, so as always to keep special design teams in the "form".

Such subordination does not require a lot of funds or investments, and requires little resources, mainly those that interact directly with "bottleneck". However, while "bottleneck" resources should be fully used, other resources should have a spare time to support the "bottleneck" in case of variations at its output.

5. "Extension" of "bottleneck". This stage consists of the following measures:

- increase in the quantity or quality of performers or in parallel working equipment;

- implementation of different methods of advanced training and more thorough control over the actions of personnel and equipment;

- using more advanced means and methods of production, effective machines and mechanisms, more effective methods and means of information processing, etc.;

- implementation of more efficient technologies.

The absence of a stage of identification and removal of "bottlenecks" in the environmental management of water ecosystems leads to risks, among which the following risks are of particular importance:
- risks of developing systems sustainability measures (false choice of inadequate design direction, unsuccessful architecture or structure, lack of prospects for further development use);

- risks of production (execution, assembly);

- risks of operation and maintenance (information provision, operating environment, security, etc.).

At the same time, the listed risks can be classified as follows:

- risk of underestimating the influence of a factor (natural or man-made);

- risk of overvaluation of the influence of a factor;

- risk of error in determining the value of a particular factor;

- the risk of a general false assessment of the situation;

- the risk of error in determining the possible consequences (current and future) caused by all previous risks.

Risk-oriented management of water ecosystems should cover:

- identification of key indicators to be achieved in order to increase the sustainability of ecosystems, preserve diversity, etc.;

- setting out parameters or factors that influence the results of management;

- identification of factors that are key to the risk;

- reduction of the probability and price of each risk;

- developing measures to mitigate each of the key risks;

- development of management plans that track the dynamics of ecosystem state change.

The management of risk-based hydrobiocenosis should include an analysis of problems from the point of view:

- possible threats (detection of the threat, its probability and price) of ecosystem stability;

- the effectiveness of achieving the goal (which key results should be realized, which factors or parameters can affect the result, which key factors affect the achievement of the goal, the probability and price of each risk).

In order to assess the risk of violations of the processes of self-regulation of ecosystems, it is necessary to have an idea of the threats that are characteristic of those or other factors in the context of the specific surrounding environment parameters of ecosystem, as well as to determine the relationship between the understanding of the processes that determine the sensitivity of the factors relevant to the dynamics of processes and degree of adequacy, authenticity and uniqueness of this reaction to natural or technogenic influences (Fig. 1). Such a connection can be represented as a sequential transition from one single factor and one parameter with one connection to a complex system under the conditions of a number of factors, parameters and relationships that can be combined between certain extrapolation procedures.

The process of awareness of the risk of reducing the sustainability of aquatic ecosystems is carried out by taking the following steps:

- identification of risk;

- identification of possible consequences in case of risk implementation;

- estimation of probability of various possible consequences;

- assessment of probability of minimizing the risk;

- assessment of the maximum consequences in case of risk implementation. 


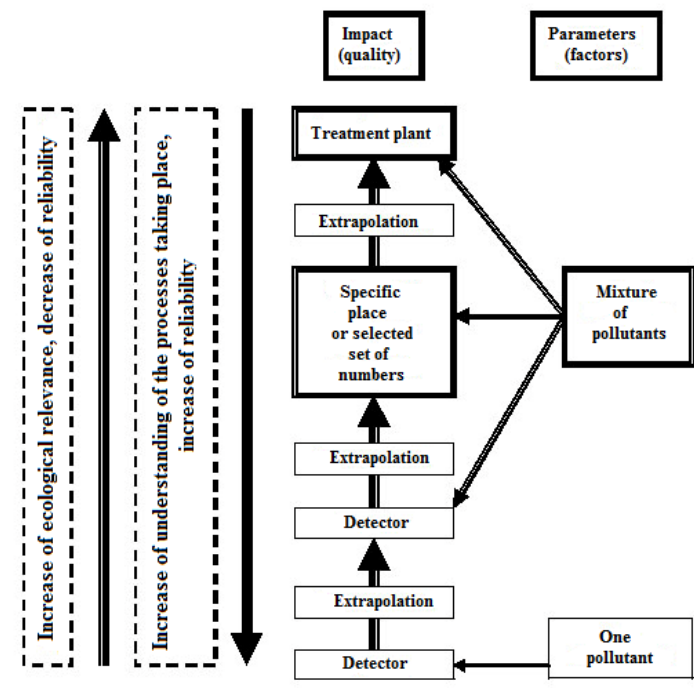

igure 1 - Connection between understanding of processes, reliability and relevancy

Since most of the risks and influences are usually not precisely assessed, it is common practice to use the linguistic scale of assessments (for example, "absent" A, "low" L, "medium" M, "significant" S), membership function and heuristic apparatus. An example of determining the membership of the value of $X$ to the corresponding linguistic variables is shown in Fig. 2.

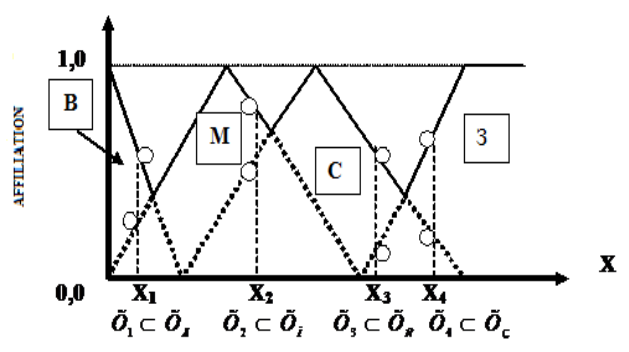

Figure 2 - Establishing the affiliation of $\mathrm{X}$ to the linguistic variable $\mathrm{A}, \mathrm{L}, \mathrm{M}$ or $\mathrm{S}$

The criteria for influencing the ecosystem can be represented as follows, where the degree of influence is given in a linguistic form with an appropriate equivalent of the relative influence. For example, the probability of an event (PE) can be characterized as probable (PRO), which occupies a probability range of $[0,8-1,0]$, possible (POS), occupying a range [0,5-0,79], unlikely (UNL), which occupies the range $[0,3-0,49]$, very unlikely (VUNL), occupying the range [0,1-0,29], and incredible (IMP), occupying the range [0,00-0,09].

On the other hand, the implementation consequences of the event can be considered as insignificant (INS), notable (NOTA), critical (CRI) and catastrophic (CAT), which can also be described in relative (to CAT category) units (respectively, INS $=\langle 0,1-0,25\rangle$, NOTA = $\langle 0,26-0,7\rangle, \mathrm{CRI}=\langle 0,71-0,89\rangle, \mathrm{CAT}=\langle 0,9-1,0\rangle$ ).

Possible risks of inadequate management of water ecosystems are presented in Fig. 3. Such risks may be due to rainfalls, be caused by dangerous microorganisms, emergency discharges of chemical enterprises, discharges of petroleum products, as well as accidents and volley discharges of untreated wastewater in waste water treatment plants.

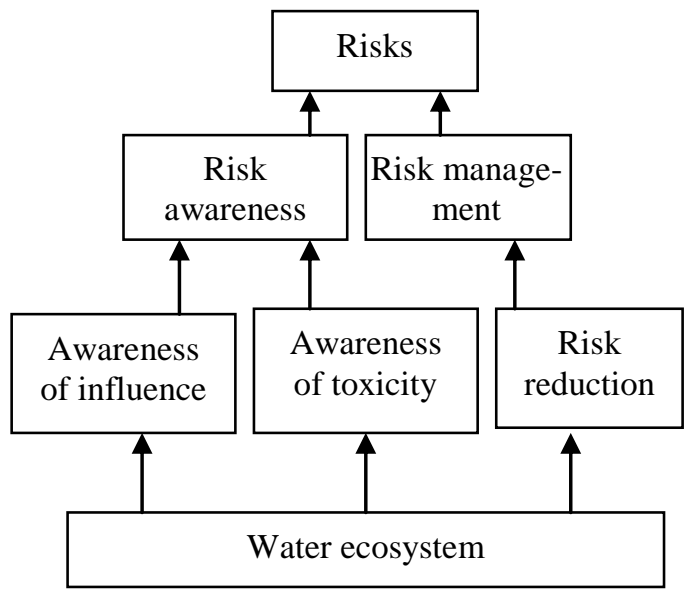

Figure 3 - Risk-oriented approach to water ecosystem management

In addition, there are risks of the impossibility of purifying sewage from a specific pollutant, as well as the priority of purification (PP) of certain pollutants, and the priority of purification is corrected by the coefficient of confidence (CC) of the purification efficiency of this particular pollutant, that is

$$
\mathrm{OPP}=\mathrm{PP} \cdot \mathrm{CC}
$$

where OPP - optimal priority of purification.

Thus for example, the priority of wastewater treatment from inorganic mercury is maximum $\left(\mathrm{PP}_{\mathrm{im}}=10\right)$, but the efficiency of its removal from wastewater is only $70 \%$, and therefore $\mathrm{OPP}_{\mathrm{im}}=10 \cdot 0,7=7$.

The identification of risks includes the following types of approaches $[17,18]$ :

- relative to the goal (any event that threatens the achievement of the goal is identified as a risk);

- relative to the action plan (various scenarios for achieving the goal are considered and any event that may lead to the development of an unwanted scenario is considered as a risk);

- relative to taxonomy (a questionnaire based on taxonomy and knowledge of positive experience is being drawn up, while the analysis of questions may reveal a risk);

- general check of risk (sometimes there are lists of possible risks, which are compared with the specific situation);

- risk rankings (all resources are classified by risk, or all threats are viewed by their impact on resources, or they consider the implications and analyze which combinations of threats and resources lead to them).

When the risk is identified and evaluated, the following approaches to risk management are used:

- avoidance (exclusion);

- reduction (softening);

- restraint;

- transfer (insurance).

Risk Indicator (Risk Price) $V \alpha R$ indicates maximum losses that will not be exceeded for a given probability and confidence interval in a given time interval. One year can be used as an interval of time in ecosystems. 
As a confidence level (probability that $V \alpha R$ will not exceed the maximum permissible losses) it is usually used $\alpha=0,95$ (i.e. $95 \%$ ). The value of $V \alpha R$ can be represented both in the quantitative (species) equivalent of biocenose losses, and in any other value. Then, at a given level $\alpha \in[0,1], V \alpha R$ is given as the smallest $q$, at which the probability $P$ of the loss $Q$ exceeds $q$ by a value that is not greater than $(1-\alpha)$ :

$$
\left.\operatorname{VaR}_{\alpha}=\inf (\mathrm{q} \in \mathrm{R} \div \mathrm{P}(\mathrm{Q}\rangle \mathrm{q}) \leq 1-\alpha\right)
$$

where inf defines the largest lower bound, $\mathrm{R}$ is the set of possible losses. In probabilistic terms $V \alpha R$ is defined as a quantile of distribution of losses.

While compiling for each source of risk the matrix "Probability of an event - the consequences of implementation" in the form, shown in Fig. 4, it is necessary to specify areas in which the consequences of the implementation by definition are:

- permissible, that is, they may take place, practically without affecting the functioning, or because of their incredible implementation;

- unacceptable;

- relatively permissible, which are reduced to the minimum possible in concrete real conditions.

\begin{tabular}{|c|c|c|c|c|}
\hline $\mathrm{PE}$ & INS & NOTA & CRI & CAT \\
\hline IMP & $\begin{array}{l}\text { Permis- } \\
\text { sible }\end{array}$ & $\begin{array}{l}\text { Permis- } \\
\text { sible }\end{array}$ & $\begin{array}{l}\text { Permis- } \\
\text { sible }\end{array}$ & $\begin{array}{l}\text { Relatively } \\
\text { permis- } \\
\text { sible }\end{array}$ \\
\hline VUNL & $\begin{array}{l}\text { Permis- } \\
\text { sible }\end{array}$ & $\begin{array}{l}\text { Permis- } \\
\text { sible }\end{array}$ & $\begin{array}{l}\text { Relatively } \\
\text { permis- } \\
\text { sible }\end{array}$ & $\begin{array}{l}\text { Relatively } \\
\text { permis- } \\
\text { sible }\end{array}$ \\
\hline UNL & $\begin{array}{l}\text { Permis- } \\
\text { sible }\end{array}$ & $\begin{array}{l}\text { Relatively } \\
\text { permis- } \\
\text { sible }\end{array}$ & $\begin{array}{c}\text { Relatively } \\
\text { permis- } \\
\text { sible }\end{array}$ & $\begin{array}{l}\text { Unaccep- } \\
\text { table }\end{array}$ \\
\hline POS & $\begin{array}{c}\text { Relatively } \\
\text { permis- } \\
\text { sible }\end{array}$ & $\begin{array}{c}\text { Relatively } \\
\text { permis- } \\
\text { sible }\end{array}$ & $\begin{array}{l}\text { Unaccep- } \\
\text { table }\end{array}$ & $\begin{array}{l}\text { Unaccep- } \\
\text { table }\end{array}$ \\
\hline PRO & $\begin{array}{c}\text { Relatively } \\
\text { permis- } \\
\text { sible }\end{array}$ & $\begin{array}{l}\text { Unaccep- } \\
\text { table }\end{array}$ & $\begin{array}{l}\text { Unaccep- } \\
\text { table }\end{array}$ & $\begin{array}{l}\text { Unaccep- } \\
\text { table }\end{array}$ \\
\hline
\end{tabular}

Figure 4 - Matrix "Probability of an event - consequences of implementation"

The use of such a matrix should occur by following way. If one or another event is considered, its probability and consequences of its implementation (based on linguistic variables or, in case of specific statistical data, on the basis of digital values that fall into the appropriate ranges) are evaluated and its place in the matrix is selected. If it is in the zone of permissible values, the analysis stops. If an event falls into an in unacceptable zone, it is necessary to provide the obligatory measures for its transfer to an acceptable or relatively permissible zone (by providing appropriate structural, programmatic or controlling, managing or compensating measures to increase the ecological safety of aquatic ecosystems).

Location in the relatively permissible zone also involves searching ways to move the event into a zone of permissible.
The optimal risk assessment for $V a R_{\text {opt }}$ will be a disjunctive mark that characterizes the maximum risk value, that is, one that meets the following condition:

$$
\mathrm{VaR}_{\mathrm{opt}}=\max \left\{\operatorname{VaR}_{1}, \ldots, \mathrm{VaR}_{\mathrm{n}}\right\},
$$

where $V a R_{\mathrm{j}}$ in the classical form corresponds to the product of the probability of the implementation of the event associated with the risk, and the amount of losses in case of its implementation.

Under conditions of uncertainty, this risk assessment should be simplified to cross the relevant probabilities of events and consequences of the implementation on the matrix, which indicates which zone it belongs to. As other risks also potentially exist and influence each other, increasing the overall risk assessment, it is necessary to determine a corrective coefficient $(\mu \geq 1)$ which takes into account the non-formalizing (or exact) determinants of additional impacts. For that, elements of the theory of fuzzy sets are also used, and all the effects are presented in the same scale. Corrective coefficient can be presented in the form

$$
\mu=1+\{(\mathrm{r}-1) \div 2 \mathrm{r}\} \sum_{\mathrm{i}=1}^{\mathrm{r}} \mathrm{k}_{\mathrm{i}}
$$

and an integral risk assessment (if there is no data on the distribution law) - respectively as

$$
\begin{gathered}
\mathrm{VaR}_{\text {opti }}=\max \left\{\mathrm{VaR}_{1}, \ldots, \mathrm{VaR}_{\mathrm{n}}\right\} \\
\mathrm{VaR}_{\text {opti }}=\mu\{2,33 \cdot \mathrm{V} \cdot \sigma \cdot \sqrt{\mathrm{T}}\},
\end{gathered}
$$

where $V$ - maximum possible loss in the case of risk implementation $R, \sigma-$ standard deviation, $\mathrm{r}-$ the number of identified risks, $\mathrm{T}-$ the term during which the risk is determined, in weeks, months, or years, 2,33the coefficient that corresponds to the confidence interval $99 \%$.

CONCLUSIONS. Management of water ecosystems under conditions of fuzzy and incomplete information or decision-making is characterized by the presence of risks that are needed to be taken into account. Riskoriented management of water ecosystems includes identification, reduction of probability and assessment of risk, development of management measures taking into account the dynamics of ecosystem state change.

The determination of the relationship between the factors of the dynamics of processes and the degree of adequacy, reliability and uniqueness of the ecosystem's response to natural and man-made influences can be represented as a sequential transition from one single factor and one parameter with one connection to a complex system under the conditions of a number of factors, parameters and connections that can be combined between extrapolation procedures. Under conditions of uncertainty, risk assessment should be simplified to the cross of relevant probabilities of events and the consequences of their implementation for the sustainability of water ecosystems. 


\section{REFERENCES}

1. Zaets, R. V. (2011), "SCP concept development and systemic issues of science and innovation updates", Proceedings of scientific conference "System Analysis and Information Technology”, p. 91.

2. Oleksienko, M. M. (2013), "Proactive approach to managing environmental projects", Management of complex systems, no. 14, pp.68-71.

3. Epting, J., Page, R., Auckenthaler, A., Huggenberger, P. (2018), "Process-based monitoring and modeling of Karst springs - Linking intrinsic to specific vulnerability", Science of The Total Environment, no. 626, pp. 403-415.

4. Drigulich, P. G., Kalinkin, O. G. (2007), "Methods of monitoring the state of the environment in the field of drilling waste disposal (on example of Andryushivsky deposit)", Oil and gas industry, no. 4, pp. 51-54.

5. Trisnyuk, V. M. (2003). "Geoecologichniy monitoryng Podilskyh Tovtr Gusiatynskogo raionu Ternopilskoi oblasti" [Geoecological monitoring of the Podilsky Tovtry within the Gusyatinsky region of the Ternopil region], "Rol pryrodozahysnyh terytoriy zahidnogo Podillia ta Yuri Ojtsovsky u zahysti biologichnogo ta landshaftnogo riznomaittia" [The role of natureprotected areas of western Podillya and Yuri Ojtsovsky in preserving biological and landscape diversity], Grimailiv, pp. 221-225.

6. Manavizadeh, N., Malek, Sh., Vosoughi-Kia, R., Farrokhi-Asl, H. (2017), "An efficient risk based multi objective project selection approach considering environmental issues", USCM, no. 5 (2), pp. 143-158.

7. Mishchenko, L. V. (2000), "Environmental audit of territories", Exploration and development of oil and gas fields, no. 37 (1), pp. 113-121.

8. Anpilova, E. S., Voloshkina, O. S., Trofimchuk, O. M., et al. (2007), "Use of GIS technologies for inventory of sources of pollution of surface waters of transboundary objects", Ecology and resources, no. 16, pp. 46-51.

9. Drusyuk, V. M. (2002), "Environmental audit and international standards", Standardization, Certification, Quality, no. 3, pp. 43-49.
10. Dmitrikov, V. P. (2004), "Basic principles of building expert systems for environmental monitoring", Stalyi rozvytok girnychoii ta metalurgichnoii promyslovosti. Tezy dopovidei mizhnarodnoi naukovo-praktychnoi konferentsii [Sustainable Development of the Mining and Metallurgical Industry: Proceedings of International scientific practical conference], pp. 255-257.

11. Klymenko, M. O., Klymenko, O. M., Petruk, A. M. (2013) "Hydroecological monitoring of water ecosystems in view of modern European directions in environmental protection activities", Bulletin of the Poltava State Agrarian Academy, no. 3, pp. 22-27.

12. Yeremeev, I. S., Dychko, A. O. (2012), "Management of quality of biochemical wastewater treatment", System Research \& Information Technologies, no. 4, pp. 45-48.

13. Dychko, A. O. (2016), Dependence of biochemical wastewater treatment from process factors, Transactions of Kremenchuk Mychailo Ostrohradskyi National University, no. 1, pp. 109-114.

14. Brack, W., Dulio, V., Ågerstrand, M. et al. (2017), "Towards the review of the European Union Water Framework Directive: Recommendations for more efficient assessment and management of chemical contamination in European surface water resources", Science of The Total Environment, no. 576, pp. 720-737.

15. Yan, Y., Qian, Y., Wang, Z., Yang, X. \& Wang, H. (2018), "Ecological risk assessment from the viewpoint of surface water pollution in Xiamen City, China", International Journal of Sustainable Development \& World Ecology, no.1, pp. 1-8, 13.

16. Chernish, E. Y., Pliatsuk, L. D. (2014), "Biological removal of phosphorus from sewage sludge during process of biosulfidogenic treatment", Transactions of Kremenchuk Mychailo Ostrohradskyi National University, no. 4, pp. 152-158.

17. Quality management systems. Requirements: DSTU ISO 9001:2009. [cited Jan. 31, 2018]. Available from:http://www.plitka.kharkov.ua/certs/433_iso9001.pdf.

18. Quality management systems. Requirements: ISO 9001:2015. [cited Jan. 31, 2018]. Available from: https://www.iso.org/standard/62085.html.

\section{АНАЛИЗ РИСКОВ И МЕНЕДЖМЕНТ ВОДНЫХ ЭКОСИСТЕМ}

\section{А. О. Дичко}

Национальный технический университет Украины «Киевский политехнический институт им. Игоря Сикорского» ул. Борщаговская, 115, Киев, 03056, Украина. E-mail: aodi@ukr.net

\section{И. С. Еремеев}

Таврийский национальный университет им. В.И. Вернадского

ул. Ивана Кудри, 33, Киев, 04000, Украина.

Функционирование системы управления водными экосистемами характеризуется отсутствием систематического подхода к анализу состояния природных водоемов, а также точного и оперативного измерения качественных и количественных показателей экологической безопасности гидросферы. Представлен анализ рисков, существующих при управлении водными экосистемами в условиях нечеткой и неполной информации. Определены риски, возникающие при экологическом менеджменте водных экосистемам и риск-ориентированном управлении экосистемой. Установлены связи между факторами динамики процессов и степенью адекватности, надежности и уникальности реакции экосистемы на природные и антропогенные факторы влияния. Представлена лингвистическая шкала оценок рисков. Разработана матрица вероятности событий устойчивости водных экосистем и последствий их реализации. В условиях неопределенности оценка рисков должна быть упрощена до соответствия вероятностей событий последствиям их реализации для устойчивости водных экосистем.

Ключевые слова: водные экосистемы, риски, менеджмент, нечеткие данные, принятие решений. 